\title{
Product Differentiation and the Irrelevancy of Input Prices for Make-or-Buy Decisions
}

\author{
Ürün Farklılaşması ve Yapma-veya-Satın Alma Kararları için Girdi Fiyatlarının Illgisizliği
}

\author{
M. Burak ÖNEMLi ${ }^{1}$
}

\begin{abstract}
Mandatory network unbundling is perhaps one of the foremost topics in regulatory economics today. The concept has crucial importance in the deregulation of many previously regulated industries including telecommunications, gas, electricity and railroads. Moreover, the topic has emerged as one of the more prominent issues associated with the implementation of the 1996 Telecommunication Act in the United States. Upon initial examination, establishing the correct costing standards and/or determining the correct input prices would seem important for sending the correct price signals to the entrants for their efficient make-or-buy decisions. However, Sappington uses a standard Hotelling location model to show that input prices are irrelevant for an entrant's make or buy decision. In this study, we show that this result is closely related to the specific conditions of the Hotelling framework. Specifically, it is shown that input prices are irrelevant when firms produce homogeneous products, but are relevant for makeor-buy decisions when the entrant and incumbent produce differentiated products under Bertrand price competition framework. These results suggest that, in general, it is important for regulators to set correct prices in order to not distort the entrants' efficient make-or-buy decisions.
\end{abstract}

Keywords: Input prices, mandatory unbundling, make-orbuy decisions, deregulation, product differentiation

\section{INTRODUCTION}

Previously regulated industries have both naturally monopolistic and potentially competitive segments. Industries such as telecommunications, electricity, natural gas, water, railroads and the postal service can be viewed as having vertical structure. Naturally monopolistic segments of these industries are often referred to as bottleneck segments. In the telecommunications industry, local loops can be regarded as the naturally monopolistic segment, while long distance and the value-added services can be regarded as potentially competitive. In the electric power industry, transmission and distribution are naturally bottleneck segments, whereas electricity generation is potentially a competitive segment. In the

\begin{abstract}
ÖZET
Zorunlu ağ ayrıştırılması, günümüzde regülasyon ekonomisinin belki de en önde gelen konularından biridir. Kavram telekomünikasyon, gaz, elektrik ve demiryolları dahil olmak üzere çok sayıda önceden düzenlemeye tabi endüstrinin deregülasyonunda çok büyük öneme sahiptir. Ayrıca, konu, Amerika Birleşik Devletleri'nde 1996 Telekomünikasyon Yasası'nın uygulanmasına bağlantılı olarak, daha bilinir meselelerden biri olarak ortaya çıkmıştır. Illk incelemede doğru maliyet standartların oluşturulması ve/veya doğru girdi fiyatlarının belirlenmesi, piyasaya yeni giren firmalara verimli yapmaveya-satın alma kararları için doğru fiyat sinyalleri göndermek açısından önemli gibi görünmektedir. Ancak, Sappington piyasaya yeni giren bir firmanın yapma-veya-satın alma kararına ilişkin girdi fiyatlarının ilgisizliğini göstermek için standart Hotelling lokasyon modelini kullanmıştır. Bu çalışmada, bu sonucun Hotelling çerçevesinin özel koşulları ile yakından ilgili olduğunu gösterdik. Spesifik olarak, firmalar homojen ürünler ürettiklerinde girdi fiyatlarının ilgisiz olduğu, fakat yeni giren firma ve yerleşik firma farklılaştırılmış ürünler ürettiklerinde yapma-veya-satın alma kararları için girdi fiyatlarının ilgili olduğu Bertrand fiyat rekabeti çercevesinde gösterilmiştir. Bu sonuçlar genel olarak düzenleyici kurumların (regülatörlerin) piyasaya yeni giren firmaların verimli yapma-veya-satın alma kararlarını bozmamak için doğru fiyatlar belirlemesinin önemli olduğunu ileri sürmektedir.
\end{abstract}

Anahtar Kelimeler: Girdi fiyatları, zorunlu kullanıma açma, yapma-veya-satın alma kararları, deregülasyon, ürün farklılaştırması

natural gas industry, pipelines are the naturally monopolistic segment, while extraction can be classified as a potentially competitive segment. Similarly, in the railroads industry, tracks and stations are in the bottleneck segment, whereas passenger and freight services are in the potentially competitive segment. All of these industries are similar in the sense that they contain both potentially competitive (bottleneck) segments and natural monopolistic segments.

Therefore, effective potential competition requires the non-discriminatory access to bottleneck segments. This is known as unbundling and/or access pricing policy, and the bottleneck input that is subject to this policy is called unbundled network elements (UNEs). Without question, unbundling and/ 
or access pricing is the main policy instrument for introducing competition in these industries. In other words, access pricing is a critical policy for deregulation of industries where a vertically integrated dominant firm controls the supply of a bottleneck input.

In the United States, the most recent and perhaps the most important example of unbundling as an industrial policy is the 1996 Telecommunications Act. ${ }^{1}$ Section 251(d)(2) of the 1996 Telecommunications Act directs the Federal Communications Commission (FCC) to determine the specific network elements that incumbent local exchange carriers (ILECs) must provide to their competitors on an unbundled basis at "cost-based" rates. ${ }^{2}$ In other words, in order to introduce competition into the telecommunications industry, the 1996 Telecommunications Act requires incumbent providers to unbundle their networks and lease individual network elements to any requesting telecommunications carrier. This concept is known as a mandatory unbundling policy and is prevalent in many network industries throughout the world. As a direct result of these unbundling policies, optimal access pricing for unbundled network elements has become a prominent issue in regulatory economics. ${ }^{3}$ Determining the optimal access charges is a complex issue and lies at the core of deregulation efforts in network industries. In other words, a sound access pricing policy is crucial for the efficient development of competition in industries with bottleneck inputs. In addition, Laffont and Tirole (2001) pointed out that an optimal access charge policy must serve numerous purposes. Specifically, an optimal access charge policy must generate efficient use of networks, encourage incumbents to invest, promote cost minimization, and create an efficient amount of entry into infrastructure, and do all this at a reasonable regulatory cost.

Laffont and Tirole (2001) observe that high access prices not only prevent society from reaching a desired level of competition by raising barriers to entry and perhaps allowing the incumbents to sustain their monopoly power in the potentially competitive segments of the industry, but also lead potential competitors to engage in socially inefficient bypass and/or duplication of facilities. Conversely, low access prices might create socially inefficient entry and discourage competitors from investing in their own facilities. Low access prices may also discourage the incumbents from maintaining and upgrading their facilities. As Laffont and Tirole (2001) point out, the access price is critical in order to give incumbents the correct signals for their choices of investment in infrastructure and induce potential competitors to enter into socially desirable segments.
The 1996 Act requires incumbent providers to supply unbundled network elements to rivals at cost-based prices. Note that the ILECs and the competitive local exchange carriers' (CLECs) have opposite assertions regarding the structure of cost-based rates. The ILECs postulate that economic efficiency requires that prices for UNEs be based on the actual, forward-looking costs. Conversely the CLECs contends that economic efficiency demands that prices for UNEs be based on the forward-looking costs of an ideally efficient ILEC as this standard is consistent with the competitive market structure that the 1996 Telecommunications Act envisioned. ${ }^{4}$ Both postulations can be criticized for different reasons. ILECS may have incentives to misreport their actual costs. Whether the inefficiencies of ILECs should be reflected in UNE prices is another point of criticism. In addition, the ILEC might not have proper incentives to achieve efficiency if UNE prices are based on actual costs. On the other hand, it is difficult to define the ideally efficient ILEC. In other words, what is the proper standard to determine that constitutes "an ideally efficient" ILEC is a subtle question to answer. Moreover as Weisman (2000, p. 196) stated "If regulators had sufficient information to implement the efficient-firm cost standard, competition would be wholly unnecessary."

The pricing methodology implemented by the U.S. Federal Communications Commission (FCC) was initially based on total element long-run incremental cost (TELRIC). ${ }^{5}$ As Gayle and Weisman (2007a, p.196) stated, "following the passage of the 1996 Act, the FCC and the individual state public service commissions engaged in efforts to determine costing standards that provide entrants with the right price signals to make or buy the input required for downstream production." The FCC has recently revisited this pricing methodology out of concern that the TELRIC methodology may yield prices that serve to distort the entrant's make-or-buy decision. ${ }^{6}$

Upon initial examination, establishing the correct costing standards and/or determining correct input prices would seem important for sending the correct price signals to entrants for their efficient make-orbuy decisions. This is not true in all cases, however. Sappington (2005), for example, uses a Hotelling location model for product differentiation to show that the entrant's efficient make-or-buy decision is independent of the price of the input. More specifically, Sappington's model reveals that the market entrants' decision for making or buying an input required for downstream production depends on a comparison 
between their cost and the incumbent's cost of making the input, rather than evaluation between their cost and the input price at which the input can be purchased from the incumbent. Sappington summarizes this result as irrelevancy of input prices for make-or-buy decision. As also stated by Weisman and Gayle (2007a), Sappington's analysis emphasizes a very important result that was first asserted in a seminal article by Chen (2001). Chen shows that a downstream firm (entrant) is able to soften downstream competition by strategically purchasing an input from a vertically integrated firm (incumbent). The reason behind such a behavior of downstream firm is that a vertically integrated firm will behave less aggressively in the downstream market when its upstream profitability is directly related to downstream competitors' demand for upstream input. According to Gayle and Weisman (2007a), competitor's strategic effect dominates the entrant's make-orbuy decision in the standard Hotelling framework. Sappington's conclusion is provocative since, if generally correct, it suggests that the efforts of the regulatory authorities to determine the correct prices for unbundled elements are largely pointless because input prices are irrelevant for efficient make-orbuy decisions.

Following Sappington (2005), Gayle and Weisman (2007a) showed that, in the vertical Bertrand competition framework, input prices are not irrelevant and they concluded that "this line of research would benefit from a more general modeling framework as opposed to the rather specialized models that we employ in this paper and that Sappington employs in his article." 7,8

There are three types of commonly used product differentiation models in literature: The Hotelling location (spatial) product differentiation, The Vertical product differentiation and Representative consumer models. The Hotelling framework for differentiated products is a horizontally differentiated approach, whereas Gayle and Weisman (2007a) use a vertically differentiated approach in their analysis. In the vertically differentiated approach, the points in the characteristic space corresponding to the set of goods lie on the same ray vector through the origin representing higher quality farther out along this ray. Therefore, if these goods were sold at the same prices, every consumer would rank these goods in the same order. Conversely, in the horizontally differentiated models the goods cannot be ranked in terms of some quality index because preferences are diverse and asymmetric. Tastes follow some distribution ac- ross the characteristic space and each consumer determines her most preferred location. An alternative approach for product differentiation is to examine the case where preferences are defined over the set of all possible goods where a central feature is preference symmetry. This approach makes extensive use of representative consumer models. ${ }^{9}$

Therefore, a natural question concerns whether contradictory results arise from inconsistencies in the definition of product differentiation. If this is the case, then a possible extension to address this inconsistency would enable us to produce more general rules for the relationship between the efficient make-or-buy decision and the irrelevancy of input prices.

This is the central idea motivating this line of research. The remainder of this essay is organized as follows. The general assumptions and definitions are outlined in Section 2. The Bertrand price competition model, as a representative consumer model, for homogeneous and differentiated products is employed and evaluated in a yardstick framework in Section 3. Section 4 summarizes the key findings and concludes. ${ }^{10}$

\section{GENERAL ASSUMPTIONS AND DEFINITIONS}

An incumbent and an entrant are assumed to compete in a duopoly setting in the market for the downstream product. Each unit of downstream output requires one unit of the upstream input and one unit of the downstream input that is self-supplied by the individual firm. The entrant has an option to buy the upstream input from the incumbent at a price which is set by the regulator. ${ }^{11,12}$ Let $w$ denote the wholesale price of the upstream input when the entrant purchases the upstream input from the incumbent. The constant unit cost of producing the upstream input for the incumbent and the entrant are denoted by $c_{u}^{I}$ and $c_{u}^{E}$, respectively. In addition, $c_{d}^{I}$ and $c_{d}^{E}$ denote the constant unit cost of producing the downstream input for the incumbent and the entrant, respectively.

\section{BERTRAND PRICE COMPETITION}

Onemli (2010) showed that Sappington's (2005) main result concerning input price irrelevance is sensitive to the underlying assumptions regarding product differentiation even in the Hotelling location sttructure. When the firms' products are differentiated in more than one characteristic, input prices are no longer irrelevant. Since the vertical differentiation model cannot allow modeling the homogene- 
ous product case, we require a somewhat different modeling framework to determine the relevance of input prices for intermediate cases between homogeneous and differentiated products. We then apply the representative consumer approach to determine whether the irrelevance of input prices exhibits a similar pattern in the cases of homogeneous and differentiated products. In this respect, a simple Bertrand price competition model for homogeneous and differentiated product cases is employed to investigate efficient make-or-buy decisions. First a duopoly setting with homogeneous products is considered. The analysis is then extended to the differentiated products case.

\subsection{Homogeneous Products Bertrand Competition}

We first note that Bertrand price competition for homogeneous products results in what has become known as the Bertrand Paradox. The Bertrand Paradox reaches the conclusion that under the assumption of two firms producing goods that are "non-differentiated" in that they are perfect substitutes in consumers' utility functions, the two firms price at marginal cost and they do not make positive profits when firms have symmetric constant costs in equilibrium..$^{13}$ In the asymmetric cost case, however, both firms set a price equal to the higher marginal cost and the firm with lower marginal cost makes a profit whereas the higher marginal cost firm realizes zero profit. However, the proof for the asymmetric marginal cost case is not as straightforward as the symmetric case. The asymmetric case gives rise to the "openness problem," and cannot be solved unless some additional assumptions are made. ${ }^{14}$

To keep the analysis simple, the downstream input cost for both firms is assumed to be zero. This assumption does not affect our model's qualitative results and yet greatly reduces non-substantive mathematical complexities. Similarly, in the Hotelling model, the incumbent is not allowed to have negative profit if the entrant prefers to buy the input from incumbent. Hence the case where $c^{I}>w$ is excluded. Otherwise, the incumbent firm would incur negative profits and would therefore not be financially viable.

Assume the incumbent and the entrant produce an identical product, and each firm incurs a marginal cost $c^{i}$ where $i=I, E$. The market demand function is given by

$$
D_{i}\left(p_{i}, p_{j}\right)=\left\{\begin{array}{cl}
D\left(p_{i}\right) & \text { if } p_{i}<p_{j} \\
\frac{1}{2} D\left(p_{i}\right) & \text { if } p_{i}=p_{j} \\
0 & \text { if } p_{i}>p_{j} .
\end{array}\right.
$$

The firms choose prices simultaneously. As stated above, the unique Nash equilibrium of this game is that both firms charge the price equal to the higher marginal cost. Therefore, the unique Nash price will be $\max \left\{c^{I}, c^{E}\right\}$ if each firm individually provides the input, and $w$ if the entrant buys the input from the incumbent.

Under the specified assumptions, whenever the entrant buys the input from the incumbent, it earns zero profit since $\Pi_{B}^{E}=(w-w) \frac{1}{2} D(w)=0$. Hence the entrant's profit is invariant to the buy decision. Notice that the incumbent's viability condition plays a crucial role here. ${ }^{15}$ Related to this, there is an interesting feature of the specified game structure that should be noted. Under the specified conditions, if the entrant purchases the input from the incumbent, the openness problem may disappear since the incumbent may not need to undercut its price in order to secure the entire market. In other words, the incumbent may find that not undercutting its price is more profitable in this case. Specifically, if the entrant purchases the input, the incumbent's profit is $\Pi_{B}^{I}=\left(w-c^{I}\right) \frac{1}{2} D(w)+\left(w-c^{I}\right) \frac{1}{2} D(w)$ which is equivalent to $\Pi_{B}^{I}=\left(w-c^{l}\right) D(w)$. However, if the incumbent undercuts its price by $\varepsilon$ to ensure that it secures the entire market, its profit will be $\hat{\Pi}_{B}^{I}=\left(w-\varepsilon-c^{I}\right) D(w-\varepsilon)$ which is lower than the previous profit if the demand function is sufficiently inelastic. The less elastic the demand function, the more likely the openness problem will disappear. Hence the incumbent will not have any incentive to secure the entire market under the specified conditions.

Let us turn our attention to the entrant's efficient make-or-buy decision. The following proposition asserts that in the homogeneous products case, the incumbent's viability constraint binds and the entrant's make-or-buy decision is independent of input prices.

Proposition 1: In the equilibrium of the homogeneous products Bertrand game: (a) the entrant prefers to make the input if and only if $c^{I}>c^{E}$ and (b) otherwise the entrant is indifferent between buying and making the input.

Proposition 1 reveals that the entrant's makeor-buy decision is irrelevant to the input price. The 
entrant makes the input whenever it is the leastcost supplier of the input. However, when it is not the least-cost supplier the entrant is indifferent to either case. To see the irrelevancy of the input price for part (b), consider the following two cases: (i) $c^{E}>w \geq c^{I}$ and (ii) $w>c^{E} \geq c^{I}$. First, in the case where $c^{E}>w \geq c^{I}$, if the entrant makes the input both firms will charge price $p=c^{E}$, and the entrant makes zero profit while the incumbent makes positive profit, $\Pi_{M}^{I}=\left(c^{E}-c^{I}\right) \frac{1}{2} D\left(c^{E}\right)$. Conversely, in the case where $c^{E}>w \geq c^{I}$, if the entrant makes the input, then the market price $p=c^{E}$, the firms' profits are $\Pi_{M}^{E}=\left(c^{E}-c^{E}\right) \frac{1}{2} D\left(c^{E}\right)=0$ and $\Pi_{M}^{I}=\left(c^{E}-c^{I}\right) \frac{1}{2} D\left(c^{E}\right)$. Hence, in the case where $c^{E} \geq c^{I}$, the entrant is indifferent to the make-or-buy decision. Comparing the cases $\left(c^{E} \geq w\right)$ and $\left(w>c^{E}\right)$ reveals that the entrant's equilibrium profit is not affected. In words, whether the entrant's marginal cost exceeds the input price that is set by the regulator or not, the entrant realizes zero profit in equilibrium. Observe that the viability condition of the incumbent plays a crucial role for the irrelevancy of input prices in the homogeneous products Bertrand framework. However this assumption plays the same role as the financial viability assumption in the standard Hotelling model.

\subsection{Differentiated Products Bertrand}

\section{Competition}

As shown in the previous sub-section, input prices are irrelevant in the homogeneous products Bertrand framework. The next logical question concerns whether this property of input prices is sensitive to the degree of product differentiation. As discussed in the introduction, there are three commonly used methods to model product differentiation. The representative consumer based product differentiation models are the most commonly used models in the literature. The following simple Bertrand competition model is one of these types of product differentiation models. Gayle and Weisman (2007b) examine the entrant's make-or-buy decision in the two-stage game framework. In the first stage, the incumbent chooses investment in innovation and competes against an entrant in the second stage. Although their model is similar to ours, they do not examine the irrelevance of input prices.

Let inverse market demand functions be given by $P^{i}=\alpha_{i}-\beta_{i} Q^{i}-\gamma Q^{j}$ where $i=I, E$ and $i \neq j .{ }^{16}$ Note that the cross-price effects are symmetric as required for well-behaved consumer demand functions. Using this inverse demand system, the direct demand system can be expressed as: $Q^{I}=a_{I}-b_{I} P^{I}+d P^{E}$ and
$Q^{E}=a_{E}+d P^{I}-b_{E} P^{E}$. Note that the relation between the parameters in the two systems can be expressed as $a_{i}=\left(\alpha_{i} \beta_{j}-\alpha_{j} \gamma\right) / \delta, b_{i}=\beta_{j} / \delta$ for $i \neq j, i=I, E$ and $d=\gamma / \delta$ where $\delta=\beta_{I} \beta_{E}-\gamma^{2}$.

Equilibrium price $(P)$, output level $(Q)$, and profits (П) of the entrant are characterized in Lemmas 1 and 2 . The equilibrium values of the variables for the entrant are denoted by the superscript $E$, and the subscript $M$ and $B$ are used to denote the equilibrium values of the make-and-buy cases, respectively.

Lemma 1: If the entrant chooses to produce the upstream input itself, its equilibrium retail prices, outputs, and profits are given, respectively, by:

$$
\begin{aligned}
& P_{M}^{E}=\frac{\left(2 a_{E} b_{I}+a_{I} d\right)+2 b_{I} b_{E}\left(c_{u}^{E}+c_{d}^{E}\right)+b_{I} d\left(c_{u}^{I}+c_{d}^{I}\right)}{\left(4 b_{I} b_{E}-d^{2}\right)} ; \\
& Q_{M}^{E}=b_{E} \frac{\left(2 a_{E} b_{I}+a_{I} d\right)-\left(2 b_{I} b_{E}-d^{2}\right)\left(c_{u}^{E}+c_{d}^{E}\right)+b_{I} d\left(c_{u}^{I}+c_{d}^{I}\right)}{\left(4 b_{I} b_{E}-d^{2}\right)} ; \operatorname{and}(2) \\
& \Pi_{M}^{E}=b_{E}\left[\frac{\left(2 a_{E} b_{I}+a_{I} d\right)-\left(2 b_{I} b_{E}-d^{2}\right)\left(c_{u}^{E}+c_{d}^{E}\right)+b_{I} d\left(c_{u}^{I}+c_{d}^{I}\right)}{\left(4 b_{I} b_{E}-d^{2}\right)}\right]^{2}
\end{aligned}
$$

Lemma 2: If the entrant chooses to buy the upstream input from the incumbent, its equilibrium retail prices, outputs, and profits are given respectively by:

$$
\begin{aligned}
& P_{B}^{E}=\frac{\left(2 a_{E} b_{I}+a_{I} d\right)+2 b_{I} b_{E}\left(w+c_{d}^{E}\right)+\left(b_{I}-d\right) d\left(c_{u}^{I}+c_{d}^{I}\right)+d^{2}\left(w+c_{d}^{I}\right)}{\left(4 b_{I} b_{E}-d^{2}\right)} ; \text { (4) } \\
& Q_{B}^{E}=b_{E} \frac{\left(2 a_{E} b_{I}+a_{I} d\right)-\left(2 b_{I} b_{E}-d^{2}\right)\left(w+c_{d}^{E}\right)+\left(b_{I}-d\right) d\left(c_{u}^{I}+c_{d}^{I}\right)+d^{2}\left(w+c_{d}^{I}\right)}{\left(4 b_{I} b_{E}-d^{2}\right)} \text { (5) } \\
& \Pi_{B}^{E}=b_{E}\left[\frac{\left(2 a_{E} b_{I}+a_{I} d\right)-\left(2 b_{I} b_{E}-d^{2}\right)\left(w+c_{d}^{E}\right)+\left(b_{I}-d\right) d\left(c_{u}^{I}+c_{d}^{I}\right)+d^{2}\left(w+c_{d}^{I}\right)}{\left(4 b_{I} b_{E}-d^{2}\right)}\right]^{2} \text {. (6) }
\end{aligned}
$$

The following proposition asserts that in the differentiated product case, the entrant's make-or-buy decision is not independent of the level of the input prices.

Proposition 2: In the equilibrium of the differentiated products Bertrand model: (a) the entrant prefers to buy the upstream input from the incumbent rather than make it if and only if $\left(w-c_{u}^{I}\right)>\left(\frac{2 b_{l} b_{E}-d^{2}}{d^{2}}\right)\left(w-c_{u}^{E}\right)$; and (b) the entrant prefers to make the upstream input itself when $\left(w-c_{u}^{I}\right)<\left(\frac{2 b_{1} b_{E}-d^{2}}{d^{2}}\right)\left(w-c_{u}^{E}\right)$.

Proposition 2, part (a) reveals that $c_{u}^{E}>c_{u}^{I}$ is not a necessary condition for the entrant to buy the input from the incumbent. When the incumbent makes zero or negative profit from the upstream market, thereby implying that $w \leq c_{u}^{I}$, the entrant's buy decision condition holds if and only if $c_{u}^{E}>c_{u}^{I}$. However, when the incumbent earns positive profit from the 
upstream market $\left(w>c_{u}^{I}\right)$, if the firms have symmetric upstream marginal $\operatorname{costs}\left(c_{u}^{I}=c_{u}^{E}\right)$, the specified inequality in the Proposition 2, part (a) holds since $\left(\frac{2 b_{I} b_{E}-d^{2}}{d^{2}}\right)>1$.

However, the case where the incumbent is the least-cost supplier $\left(c_{u}^{E}>c_{u}^{I}\right)$ is ambiguous. In this case, the entrant may or may not buy the upstream input. Specifically, as the firms upstream production costs converge to one another and when $\left(\frac{2 b_{I} b_{E}-d^{2}}{d^{2}}\right)$ is sufficiently close to 1 , the entrant is less likely to buy the upstream input. In other words, when $c_{u}^{E}>c_{u}^{I}$, the entrant would prefer to make the input for a sufficiently large input price $w$, implying that $\left(w-c_{u}^{l}\right)<\left(\frac{2 b_{l} b_{E}-d^{2}}{d^{2}}\right)\left(w-c_{u}^{E}\right)$ is a possibility in this case. This case also underscores the relevancy of input prices because it is possible for the entrant to have a higher upstream input production cost and still prefer to make the upstream input instead of buying it from the incumbent. Hence, within the limits of the model specified here, the input price is not irrelevant for the entrant's make-or-buy decision.

Note that the conditions of Proposition 2 moves toward the homogeneous products case when $\left(\frac{2 b_{I} b_{E}-d^{2}}{d^{2}}\right)$ approaches 1 since $\left(\frac{2 b_{I} b_{E}-d^{2}}{d^{2}}\right)$ measures the degree of product differentiation. When $\left(\frac{2 b_{I} b_{E}-d^{2}}{d^{2}}\right)$ equals 1 , this implies that $b_{I}=b_{E}=d$, and the demand system may not be well-defined. However, it is possible to say that as $\left(\frac{2 b_{I} b_{E}-d^{2}}{d^{2}}\right)$ approaches 1 in the limit, the products of the firms become more homogeneous and the greater the degree of homogeneity, the less relevant are input prices in equilibrium. Hence, this framework suggests that the irrelevancy of input prices depends on the degree of product differentiation. Specifically, within the Bertrand competition setting, if the entrant's and incumbent's products are homogeneous, then the input prices are irrelevant. Conversely when both firms' products are differentiated, the input prices become relevant.

\section{SUMMARY AND CONCLUSION}

The primary objective of this paper is to examine the relationship between product differentiation and the irrelevance of input prices for the entrants' makeor-buy decisions. We find that Sappington's main result on the irrelevance of input prices is sensitive to the particular level of product differentiation in the representative consumer approach. Specifically, Sappington's results concerning the irrelevance of input prices depend on the limitations of the standard Hotelling location model for product differentiation.

It is shown that even under the Bertrand price competition framework, Sappington's main result concerning the irrelevance of input prices for make-or-buy decisions is undermined. Our findings serve to establish that input prices for make-or-buy decisions are irrelevant if the incumbent and the entrant produce identical products, and relevant if the firms produce differentiated products. The policy implications of these results are important. Unless the incumbent's and entrant's products are perfectly homogeneous, regulatory agencies should seek to set efficient prices to minimize distortions.

The models employed in this study treat product differentiation as independent from the actions of firms since the product differentiation definition relies solely on consumer preferences. Therefore, the static game structure given in this context yields the same results with those of sub games when the game structure is extended to the repeated game. In other words, when product differentiation is assumed to be exogenous, the qualitative results of given static game are parallel to those of the sub games in dynamic setting. However, in reality firms exert significant effort and go to great expense to differentiate their products from those of their rivals. The implication being that the results of the static games may deviate from the equilibrium values of sub games in dynamic game structure. Specifically, with this extension, the entrant will seek to maximize its dynamic or inter-temporal profits rather than focusing on profits of a specific period as a result of myopic behavior. Additionally, new products may require upgraded technology facilities by reducing amount and kinds of elements that can be bought from the incumbent. Thus, employing models where the degree of product differentiation is endogenous to the firms may be a fruitful avenue for future research. 


\section{END NOTES}

*Grateful to Dennis L. Weisman and two anonymous referees for helpful comments.

${ }^{1}$ The 1996 Telecommunication Act Section 251 (d) (2): In determining what network elements should be made available for purposes of subsection (c) (3), the Commission shall consider, at a minimum, whether

(A) access to such network elements as are proprietary in nature is necessary; and

(B) the failure to provide access to such network elements would impair the ability of the telecommunications carrier seeking access to provide the services that it seeks to offer.

${ }^{2}$ See Kahn,Tardiff and Weisman (1999) for a comprehensive discussion of the economics underlying the 1996 Telecommunications Act.

${ }^{3}$ See Armstrong, Doyle and Vickers (1996), Amstrong and Vickers(1998) and Armstrong (2002) for a comprehensive analysis of access pricing. See Hausman and Sidak (1999) for the effects of unbundling policies on consumer welfare. See Crandall, Ingraham and Singer (2004) and Hazlett (2006) for the effect of mandatory network sharing on facilities-based investment.

${ }^{4}$ See Weisman (2000) and Weisman (2002).

5 TELRIC costs are determined based on the cost structure of an "ideally-efficient" provider. See Weisman (2000) and Kahn, Tardiff and Weisman (1999) for comprehensive discussion of these issues.

${ }^{6}$ See the FCC(2005, para 220). The FCC continued this line of thinking when it removed mass market switching as an unbundled network element, in part, because TELRIC-based prices for switching discouraged investment in facilities-based networks.

${ }^{7}$ See Gayle and Weisman (2007a, p. 201).

${ }^{8}$ Following Gayle and Weisman (2007a), Mandy (2009) showed that input prices are relevant except for make-or-buy decisions except under restrictive assumptions on the demand structure in a more general setting.

${ }^{9}$ See Beath and Katsoulacos (1991) for an extensive review of the literature on production differentiation.

${ }^{10}$ It is not possible to use the vertical differentiation model as a complete yardstick model since the homogeneous product case cannot be examined using this framework.

${ }^{11}$ Note that following Sappington (2005), Gayle and Weisman (2007a), we focus on one-way access pricing. In one-way access pricing only competitors require vital inputs from the incumbent. In the case of two-way access pricing, all firms in the market need to purchase critical inputs from each other.

${ }^{12}$ The regulator attempts to set an input price that is lower than the monopoly price of the product to allow effective downstream competition.

${ }^{13}$ See Tirole (1989, p. 209-211).

${ }^{14}$ In the asymmetric cost case, the firm with lower marginal cost actually wants to set a price $\varepsilon$ below the high-cost firm's marginal cost to secure the entire market. It wants to choose infinitesimally close to 0 , but such an $\varepsilon$ does not exist. See Tirole (1989, p. 234).

${ }^{15}$ Since $w \geq c^{l}$ whenever the entrant buys the input, both firms charge $p=w$, so the entrant makes zero profit in equilibrium.

16 These linear inverse demand functions are obtained from Singh and Vives (1984). Singh and Vives model an economy with a monopolistic sector with two firms, each one producing a differentiated good, and a competitive numeraire sector. In their linear model, there is a continuum of consumers of the same type with a utility function separable and linear in the numeraire good, implying there are no income effects on the monopolistic sector. The representative consumer maximizes $U\left(q_{1}, q_{2}\right)-\sum_{i=1}^{2} p_{i} q_{i}$. The utility of the consumer is assumed to be quadratic and strictly concave $U\left(q_{1}, q_{2}\right)=\alpha_{1} q_{1}+\alpha_{2} q_{2}-\left(\beta_{1} q_{1}^{2}+2 \gamma q_{1} q_{2}+\beta_{2} q_{2}^{2}\right) / 2$, where $\alpha_{i}$ and $\beta_{i}$ are positive, $i=1,2, \beta_{i} \beta_{j}-\gamma^{2}>0$, and $\alpha_{i} \beta_{j}-\alpha_{j} \gamma>0$ for $i \neq j, i=1,2$. Hence, this utility function yields a linear demand structure with inverse demands given by $P^{i}=\alpha_{i}-\beta_{i} q_{i}-\gamma q_{j}$. 


\section{REFERENCES}

Armstrong, M. (2002) "The theory of Access Pricing and Interconnection" M.E. Cave, S.K. Majundar and I. Vogelsang (eds.) Handbook of Telecommunications Economics, Amsterdam, Elsevier Science.

Armstrong, M., Doyle, C. and Vickers, J., (1996) "The Access Pricing Problem: A Synthesis" Journal of Industrial Economics, 44:131-150.

Armstrong, M. and Vickers, J. (1998) "The Access Pricing Problem with Deregulation: A Note" Journal of Industrial Economics, 46:115-121.

Beath, J. and Katsoulacos, Y. (1991) The Economic Theory of Product Differentiation, New York, Cambridge University Press.

Chen, Y. (2001) "On Vertical Mergers and Their Competitive Effects" RAND Journal of Economics, 32:667-685.

Crandall, R., Ingraham, A., and Singer, H. (2004) "Do Unbundling Policies Discourage CLEC FacilitiesBased Investment?" The B.E. Journals in Economic Analysis \& Policy, 1-23.

Gayle, P. G., and Weisman, D. L. (2007a) "Are Input Prices Irrelevant for Make-or-Buy Decisions?" Journal of Regulatory Economics, 32:195-207.

Gayle, P. G., and Weisman, D. L. (2007b) "Efficiency Trade-Offs in the Design of Competition Policy for the Telecommunications Industry" Review of Network Economics, 6:321-341.

Hausman, J. and Sidak, J. (1999) "A Consumer Welfare Approach to Mandatory Unbundling of Telecommunications Networks" Yale Law Journal, 109:417-505.
Hazlett, T. W. (2006) "Rivalrous Telecommunications Networks with and Without Mandatory Network Sharing" Federal Communications Law Journal, 58:477510.

Hotelling, H. (1929) "Stability in Competition." Economic Journal, 39(154):41-57.

Kahn, A.E, Tardiff, T. J. and Weisman D. L. (1999) "The Telecommunications Act at Three Years: An Economic Evaluation of Its Implementation by the Federal Communications Commission" Information Economics and Policy, 11:319-365.

Laffont, J.-J., and Tirole, J. (2001) Competition in Telecommunications, Cambridge, Massachusetts, The MIT Press.

Mandy, D. M. (2009) "Pricing Inputs to Induce Efficient Make-or-Buy Decisions" Journal of Regulatory Economics, 36:29-43.

Onemli, B. (2010) Three Essays on Regulatory Economics, Ph.D. Thesis, Kansas State University.

Sappington, D. E. M. (2005) "On the Irrelevance of the Input Prices for Make-or-Buy Decisions" American Economic Review, 95(5):1631-1638.

Singh, N. and Vives, X. (1984) "Price and Quantity Competition in a Differentiated Duopoly" The RAND Journal of Economics, 15(4):546-554.

Tirole, J. (1989) The Theory of Industrial Organization, Cambridge, MA, MIT Press.

Weisman, D. L. (2000) "The (In)Efficiency of the Efficient Firm Cost Standard” Antitrust Bulletin, 45:195211. 